\title{
Allozyme heterozygosity and homeostasis in germinating seeds of jack pine
}

\author{
D. R. Govindaraju* and \\ B. P. Dancik
}

Department of Forest Science, The University of Alberta, Edmonton, Alberta, Canada T6G $2 \mathrm{H} 1$.

The concept of pherotypic stability used in plant breeding was employed to test the relationship among allozyme heterozygosity, growth rate, and homeostasis, using seed germination as a model, in 51 open-pollinated families of jack pine. The seeds were germinated in petri dishes in nine variably stressful environments. Mean radicle length per individual in each family germinated in a specific environmental stress was then correlated with the amount of allozyme heterozygosity of the respective family. A significant positive relationship between mean radicle length and allozyme heterozygosity was found in three out of nine environments. Phenotypic stability values had a significant positive relationship with mean radicle length, but showed no relationship with allozyme heterozygosity. We conclude that environmental variation may be partially responsible for the strength of relationship between allozyme heterozygosity and growth rate; which is consistent with the notion that genotype-environment interactions are important determinants in the expression of heterosis.

\section{INTRODUCTION}

A linear relationship between heterozygosity and hybrid vigour (heterosis) for various traits, such as growth rate, productivity, and reproductive performance has been recognized by plant and animal breeders (Neal, 1935; East, 1936; Sentz et al., 1954; Rowe and Cockerham, 1963; Sheridan, 1981). In plants, heterosis is expressed throughout the life cycle, ranging from traits such as rate of germination to yield and biomass, and their components (Sinha and Khanna, 1976, and references therein). Heterosis is known to provide greater resilience to environmental perturbations (Maynard Smith et al., 1955; Lewontin, 1956), and the combined biological properties of heterotic individuals have been termed genetic homeostasis (Lerner, 1954). Following the results of plant and animal breeders, several workers have argued that allozyme heterozygosity may also be used as a predictive index of both quantitative traits and genetic homeostasis (Mitton, 1983; Mitton and Grant, 1984).

In plant breeding studies, homeostasis is frequently estimated using phenotypic stability

\footnotetext{
* Present address: Department of Forestry, University of Kentucky, Lexington, KY 40546, U.S.A.
}

models (Eberhart and Russell, 1966; Hanson, 1970; Freeman, 1973). These models assume that the most stable genotype will show the least variance in a particular quantitative trait across environments. With this assumption, stability is measured in terms of regression (stability index or "b." value) of a quantitative trait of a given genotype in different environments on the respective means of all genotypes. These analyses, in general, have shown a linear and tripartite relationship among heterozygosity, productivity, and stability (Adams and Shank, 1959; Allard, 1961; Pfahler, 1966). Therefore, plant breeders have termed phenotypic stability as equivalent and commutative to the concept of genetic homeostasis (Becker, 1981). In studies dealing with biochemical genetic variation, genotypes are often defined in terms of allozymes, because they are closer approximates of the genotype (Ayala, 1976), and their expression, unlike quantitative characters, is less susceptible to environmental influences. Furthermore, a positive relationship between low variance and low asymmetry for phenotypic traits and high allozyme heterozygosity has been reported (Soule, 1979; Mitton, 1978; Eanes, 1981). Similarly, a positive correlation $(0.95$ to 0.99$)$ between variances and stability (b) values has been reported for corn, barley and oats (Becker, 1981). 
Clearly, the approaches used toward understanding the nature of homeostasis are fundamentally identical both in plant breeding and in allozyme studies. Therefore, it could be argued that stability analysis may be extended to examine the relationships among growth rate, allozyme heterozygosity, and homeostasis.

The specific objectives of this study are: (a) to understand the relationship between phenotypic stability (homeostasis) and allozyme heterozygosity, and (b) to study the relationship between allozyme heterozygosity and rate of germination under varying degree of environmental stresses. Data on the relationship between allozyme heterozygosity and growth rate under stressed conditions are rare (Mitton and Grant, 1984). The rate of germination of seeds is a genetically controlled trait (Whittington, 1973), and the heterosis expressed at the time of germination influences the subsequent development and growth of plants (Ashby, 1937; Hayes et al., 1955). Therefore, an analysis of the relationship between genetic variation, and stability of germinating seeds under controlled conditions would be useful as a predictive model to understand the genotypic response to environmental stresses.

\section{MATERIAL AND METHODS}

The seed material used in this study consisted of 51 open-pollinated families of jack pine (Pinus banksiana Lamb.). Thirty five of these families originated from a single stand near Bruderheim in central Alberta, and the rest were obtained through the courtesy of Dr J. Klein of the Northern Forest Research Centre, Edmonton, Alberta. The experiment was laid out in a randomised block design with nine treatments (environmental stresses) and three replications, and was carried out in spring 1983. Four sets of environmental stresses were included in the study. They are (1) control (deionised water), (2) salinity (sodium chloride; $-1 \cdot 14$, $-2 \cdot 29,-3 \cdot 43$ bars), (3) radiation $(1 \cdot 5,3 \cdot 0$, $4.5 \mathrm{KR})$, and (4) heavy metal ( $12.5 \mathrm{ppm}$ copper sulphate, and $25 \mathrm{ppm}$ zinc sulphate). Although all of these stresses may affect the growth and evolution of many of the species in the genus Pinus, only water stress (set 2) may be relatively more important as a stress factor in the distribution range of jack pine. The species typically grows on poor, dry, sandy and acidic soils to fertile loamy soils (Harlow and Harrar, 1969). The control was also considered as one of the stress factors, and the levels of stresses used were arbitrary.
Ten seeds from each family were placed in $9 \times 1 \mathrm{~cm}$ petri dishes on Whatman No. 1 filter paper, and each petri dish was considered as one replication. Filter papers in the petri dishes were moistened once every three days with $5 \mathrm{ml}$ of the appropriate solution, from the day of sowing. The seeds were allowed to germinate for 12 days under greenhouse conditions. Ninety eight to $100 \mathrm{per}$ cent germination was found in the families examined; ungerminated seeds were excluded from the study. Data were recorded on five randomly chosen radicles from each family and each replication. The length of radicle is a metric trait, and therefore it was considered to be governed by polygenic inheritance.

Average amount of heterozygosity $(\bar{H}$; Ayala, 1976) per family was determined by horizontal starch-gel electrophoresis of tissue extracts from seven elongating radicles of week-old germinating seeds. Sixteen enzyme systems encoded by 22 loci were analyzed. The loci studied were: ACP-1; ACO; AK; ADH; AAT-1,2,3; DIA-1; FLE; GDH; G2DH; G6PD; IDH; MDH-1,2,3; ME; PGI-1,2; PGM; and 6PGD-1,2. It was assumed that allozyme heterozygosity in elongating radicles represented the genetic variation of each family for the systems examined (Govindaraju and Dancik, 1986). Means, standard errors, and pooled analysis of variance were calculated using the SPSS package (Nei et al., 1975). Stability analysis (Eberhart and Russell, 1965) was carried out according to the following model:

$$
Y_{i j}=\mu_{i}+\beta_{i} I_{j}+\delta_{i j}
$$

where, $Y_{i j}=$ the mean radicle length of the $i$ th family in $j$ th environment, $\mu_{i}=$ the mean of $i$ th family over all environments, $\beta_{i}=$ the regression coefficient that measures the response of the $i$ th family to varying environments, $\delta_{i j}=$ the deviation from regression of the $i$ th family in $j$ th environment, and $I_{J}=\left(\left(\sum Y_{i j} / v\right)-\left(\sum \sum Y_{i j} / v n\right)\right)$, which is the mean of all families in the $j$ th environment minus the grand mean; $v$ are families tested in $n$ environments. This is one of the most frequently used models to measure biological stability in crop plants (Becker, 1981). The Spearman rank correlation $\left(r_{s}\right)$ was used to evaluate the following relationship: (i) phenotypic stability (b) values with mean radicle length, as well as average heterozygosity of the respective family, and (ii) average heterozygosity with mean radicle length in each of the nine environments for the families studied. 


\section{RESULTS AND DISCUSSION}

Significant variation among families, as well as environments was found for radicle length (table 1), suggesting that families show differential responses to environmental stresses. Average heterozygosity ranged from 9 to 36 per cent (Mean $=20 \cdot 84$; S.D. $=7 \cdot 28)$. The mean length of radicles was higher under controlled conditions (environment 1) as expected, than in any other environments, and decreased with the magnitude of stress (table 2). Significant positive relationships between allozyme heterozygosity and mean radicle length were found only in relatively highly stressed environments.

Positively significant correlations between growth rate and heterozygosity in our study, specifically under highly stressed environmental conditions, suggest that the environmental may play an important role in determining the intensity of the expression of allozyme heterozygosity (heterosis). The largest degree of heterosis for morphological traits has been found under severe stresses in maize (McWilliam and Griffing, 1965), tobacco (Pederson, 1968), and Drosophila pseudoobscura (Parsons, 1971). Barlow (1981) reviewed several examples of the expression of heterosis from various plant and animal breeding experiments and concluded that, "heterosis by environment interaction is the expectation rather than the exception".

The correlation between phenotypic stability (b) and mean radicle length was significant $\left(r_{s}=\right.$ 0.530 ; fig. 1), but not between heterozygosity and phenotypic stability $\left(r_{s}=0.004\right.$; fig. 2$)$. The association between phenotypic stability and growth rate of radicles is in agreement with previous findings (Knight, 1970). On the other hand, our study showed no apparent relationship between allozyme heterozygosity and stability, although the relationship between heterozygosity and growth rate was specific to stressed conditions. While stability is a genetically controlled trait

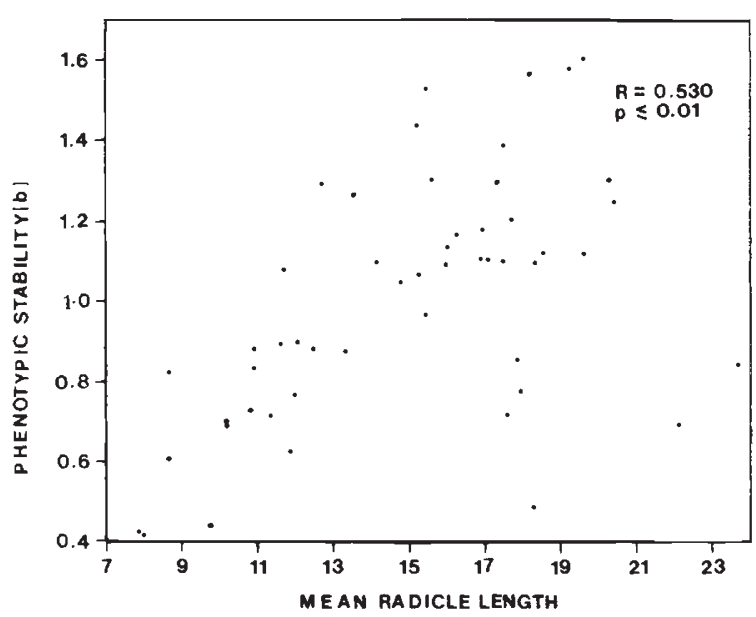

Figure 1 Association between phenotypic stability $(b)$ and mean radicle length.

(Mather, 1953), the relationship between stability and productivity is not universal (Hardwick, 1981); individual families show either general or specific environmental sensitivities (Connolly and Jinks, 1975). Therefore, it is likely that the expression of allozyme heterozygosity may be partly governed by the environment, which is in accordance with Griffing and Zsiros (1971), who indicated that heterosis may not be "entirely the result of genetic stimuli but the result of the interaction between genetic and environmental stimuli".

While several studies show a positive relationship between multi-locus allozyme heterozygosity and quantitative traits such as growth rate or fertility or both (Knowles and Mitton, 1980; Mitton and Grant, 1980; Garton et al., 1984), examples of inconsistent relationship between these two attributes are equally common (Hauptli and Jain, 1980; Nevo et al., 1982; Giles, 1984; Chakraborty et al., 1986; McAndrew et al., 1986; Price et al., 1986). The inconsistent relationship between allozyme heterozygosity and growth rate across environments, in this study, could be due to large

Table 1 Pooled analysis of variance for radicle length

\begin{tabular}{lrcc}
\hline Source & DF & Mean squares & \multicolumn{1}{c}{$\mathrm{F}$} \\
\hline Environment & 8 & $69,200 \cdot 50$ & $126 \cdot 91^{* *}$ \\
Family & 50 & $2,084 \cdot 22$ & $45 \cdot 68^{* *}$ \\
Replication (Environments) & 18 & $82 \cdot 65$ & $1 \cdot 81^{*}$ \\
Family $\times$ Environment & 400 & $463 \cdot 00$ & $10^{* * 15^{* *}}$ \\
Family $\times$ Replication (Env.) & 900 & $45 \cdot 62$ & $2 \cdot 47^{* *}$ \\
Error & 5508 & $18 \cdot 44$ & \\
\hline
\end{tabular}

${ }^{*} p<0.05, * * p<0.01$. 
Table 2 Mean radicle length and its relationship with allozyme heterozygosity under different environmental conditions

\begin{tabular}{|c|c|c|c|}
\hline Environments & Description & $\begin{array}{l}\text { Mean } \\
(\mathrm{mm})\end{array}$ & $\begin{array}{l}\text { Corr. with alz. } \\
\text { heterozygosity }\left(r_{s}\right)\end{array}$ \\
\hline 1 & Deionized water & $33.79 \pm 13.02$ & 0.00 \\
\hline 2 & Salt level 1 & $13 \cdot 38 \pm 5 \cdot 77$ & $0 \cdot 21$ \\
\hline 3 & Salt level 2 & $5 \cdot 51 \pm 3 \cdot 54$ & $0 \cdot 31^{*}$ \\
\hline 4 & Salt level 3 & $2.00+1.86$ & $0 \cdot 31^{*}$ \\
\hline 5 & Radiation level 1 & $18 \cdot 20 \pm 9 \cdot 83$ & $0 \cdot 23$ \\
\hline 6 & Radiation level 2 & $12 \cdot 78 \pm 9 \cdot 44$ & $0 \cdot 22$ \\
\hline 7 & Radiation level 3 & $8 \cdot 48 \pm 8 \cdot 26$ & $0 \cdot 32^{*}$ \\
\hline 8 & Copper Sulphate & $17 \cdot 11 \pm 6 \cdot 25$ & 0.09 \\
\hline 9 & Zinc Sulphate & $21 \cdot 83 \pm 7 \cdot 37$ & $0 \cdot 16$ \\
\hline
\end{tabular}

$* p<0.05$.

variations in the estimates of heterozygosities rather than low correlation with the quantitative character (Archie, 1985). Alternatively, these variables may be governed by different sets of genes (Mukai and Cockerham, 1977; MacIntyre, 1982). Also, polygenic variation is typically controlled by additive and non-additive genetic factors (Falconer, 1981), and the loci responsible for additive genetic variance (variation in growth rate) are different from those of polymorphic protein (Tachida and Mukai, 1985).

There have been many attempts to use allozyme variation as predictive indices of morphological traits in various plants (Tanksley et al., 1982, and see also Tanksley and Orton, 1983). Recently, Mitton and Grant (1984) have advanced several justifications in favour of using allozyme heterozygosity as a predictor of productivity and homeostasis in plant and animal systems. Our results, however, show that the use of allozyme hetero-

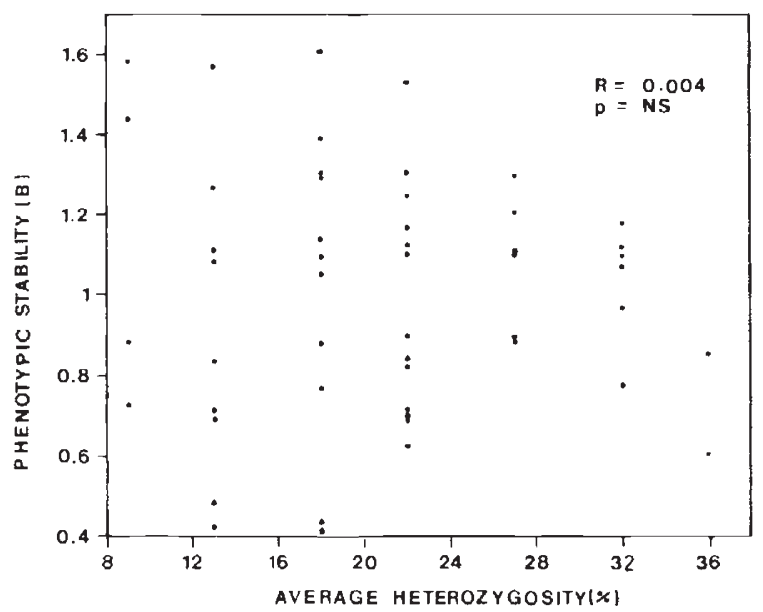

Figure 2 Association between phenotypic stability $(b)$ and allozyme heterozygosity. zygosity as an index of phenotypic stability (homeostasis) may be limited, but its value as a predictor of heterosis among quantitative traits may be greater under environmental stresses.

Acknowledgement We thank G. Furnier, D. Wagner and an anonymous reviewer for useful suggestions, and to NSERCC for financial support (SPF-0041) to D.R.G. It is a pleasure to acknowledge the help of Drs G. P. Berlyn, J. R. Powell and M. A. Srinivasan during the stay of one of us (D.R.G.) at Yale, in summer, 1986. Ms. B. L. Kamala typed several drafts of this paper.

\section{REFERENCES}

ADAMS, M. W. AND SHANK, D. B. 1959. The relationship of heterozygosity and homeostasis in maize hybrids. Genetics, 44, 777-786.

ALLARD, R. W. 1961. Relationship between genetic diversity and consistency of performance in different environments. Crop Sci., 1, 127-133.

ARCHIL: J. W. 1985. Statistical analysis of heterozygosity data: independent comparisons. Evolution, 39, 623-637.

ASHBY, E. 1937. Studies on the inheritance of physiological characters. 111. Hybrid vigor in the tomato. Part 1. Manifestations of hybrid vigor from germination to the onset of flowering. Ann. Bot., 1, 11-41.

AY^LA, F. J. 1976. Molecular genetics and evolution. In Ayala, F. J. (ed.) Molecular Evolution, Sinauer Associates, Inc., Sunderland, Massachusetts, pp. 1-20.

BARLOW. R. 1981. Experimental evidence for interaction between heterosis and environment in animals. Anim. Breed. Abst., 49, 715-737.

BECKER, H. C 1981. Correlations among some statistical measures of phenotypic stability. Euphytica, 30, 835-840.

(HAKRABORTY, R., FERRELL, R. E., BARTON, S. A. AND SCHUI.I., W. I. 1986. Genetic polymorphism and fertility parameters in the Ayamara of Chile and Bolivia. Ann. Hum. Genet., 50, 69-82.

CONNOILY, V. AND JINKS, J. L. 1975. The genetical architecture of general and specific environmental sensitivity. Heredity, $35,249-259$. 
EANES, W. F. 1981. Morphological variance and enzyme heterozygosity in the monarch butterfly. Nature, 276, 263264.

EAST, E. M. 1936. Heterosis. Genetics, 21, 375-397.

EBERHART, S. A. AND RUSSELL, W. A. 1966. Stability parameters for comparing varieties. Crop Sci., 6, 26-40.

FALCONER, D. S. 1981. Introduction to Quantitative Genetics. Longman, London.

FREEMAN, G. H. 1973. Statistical methods for the analysis of genotype-environment interactions. Heredity, 31, 339-354.

GARTON, D. W., KOEHN, R. K. AND SCOTT, T. M. 1984. Multiplelocus heterozygosity and the physiological energetics of growth rate in the coot clam. Mulina leteralis, from a natural population. Genetics, 108, 445-455.

GILES, B. A. 1984. A comparison between quantitative and biochemical variation in the wild barley Hordeum murinum. Evolution, 38, 34-41.

GOVINDARAJU, D. R. AND DANCIK, B. P. 1986. Relationship between allozyme heterozygosity and biomass production to jack pine (Pinus banksiana Lamb.) under different environmental conditions. Heredity, 57, 145-148.

GRIFFING, B. AND ZSIROS, D. E. 1971. Heterosis associated with genotype-environment interactions. Genetics, $68,443-$ 455 .

Hanson, w. D. 1970. Genotypic stability. Theor. Appl. Genet., 40, 226-231.

HARDWICK, R. C. 1981. The analysis of genotype $\times$ environment interactions: what does it mean if varietal stability is linearly related to varietal performance? Euphytica, 30, 217-221.

HARLOW, W. M. AND haRRAR, E. S. 1969. Text Book of Dendrology. McGraw-Hill Book Company, New York.

HAUPTLI, H. AND JAIN, S. K. 1980. Genetic polymorphisms and yield components in a population of amaranths. $J$. Hered., 71, 290-292.

HAYES, H. K., 1MMER, F. R. AND SMITH, D. C. 1955. Methods of Plant Breeding. McGraw-Hill, New York.

KNIGHT, R. 1970. The measurement and interpretation of genotype-environment interactions. Euphytica, 19, 225235.

KNOWLES, P. AND MITTON, J. B. 1980. Genetic heterozygosity and radial growth variability in Pinus contorta. Silvae Genetica, 29, 114-117.

LERNER, I. M. 1954. Genetic Homeostasis, Oliver and Boyd, Edinburgh.

LEWONTIN, R. C. 1956. Studies on homeostasis and heterozygosity. I. General considerations. Abdominal bristle number in second chromosome homozygotes of Drosophila melanogaster. Am. Nat., 90, 237-245.

MACINTYRE, R. 1. 1982. Regulatory genes and adaptation: past, present, and future. Evol. Biol., 15, 247-285.

MATHER, K. 1953. Genetical control of stability. Heredity, 7, 297-336.

MAYNARD SMITH, J., CLARKE, J. M. AND HOLLINGWORTH, M. J. 1955. The expression of hybrid vigor in Drosophila suboobscura. Proc. Roy. Soc. Ser. B., 114, 159-171.

M(ANDRIW, B. J., WARI), R. D. AND BEARDMORE, J. A. 1986 Growth rate and heterozygosity in the plaice, Pleuronectes platessa. Heredity, 57, 171-180.

MCWILliAM, J. R. AND GRIFFING, B. 1965. Temperaturedependent heterosis in maize. Aust. J. Biol. Sci., 18, 569-583.

MITTON, J. B. 1978. Relationship between heterozygosity for enzyme loci and variation of morphological characters in natural populations. Nature, 273, 661-662.
MitTon, J. B. 1983. Conifers. Tanksley, S. and Orton, T. (eds.) Isozymes in Plant Genetics and Breeding, Part B, Elsevier Science Publishers, Amsterdam, pp. 443-472.

MITTON, J. B. AND GRANT, M. C. 1980. Observations on the ecology and evolution of quaking aspen, Populus tremuloides in the Colorado Front Range. Am. J. Bot., 67, 200-209.

MITTON, J. B. AND GRANT, M. C. 1984. Associations among protein heterozygosity growth rate, and developmental homeostasis. Ann. Rev. Ecol. Syst., 15, 479-499.

MUKAI, T. AND COCKERHAM, C. C. 1977. Spontaneous mutation rates at enzyme loci in Drosophila melanogaster. Proc. Natl. Acad. Sci., 74, 2514-2517.

NEAL, N. P. 1935. Decrease in yielding capacity in advanced generations of hybrid corn. J. Amer. Soc. Agron., 27, 266270 .

NEI, N. H., HULL, C. H., JENKINS, J. G., STEINBRENNER, K AND BENT, D. H. 1975. SPSS: Statistical Package for the Social Sciences, Second edition. McGraw-Hill, New York, NY.

NEVO, E., GOLDBERG, E., BEILES, A., BROWN, A. H. D. AND ZOHARY, D. 1982. Genetic diversity and environmental associations of wild wheat Triticum dicoccoides in Israel. Theor. Appl. Genet., 62, 241-254.

PARSONS, P. A. 1971. Extreme-environment heterosis and genetic loads. Heredity, 26, 479-483.

PEDERSON, D. G. 1968. Environmental stress, heterozygote advantage, and genotype-environment interaction in Arabidopsis. Heredity, 23, 127-138.

PFAHLER, P. L. 1966. Heterosis and homeostasis in rye (Secale cereale L.) II. Production of varieties, intravarietal crosses and composite populations under various population densities. Crop Sci., 6, 401 405.

PRICE, S. C., KAHLER, A. L., HALlauer, A. R., CHARMLEy, P. AND GIEGEL, D. A. 1986. Relationships between performance and multilocus heterozygosity at enzyme loci in singlecross hybrids of maize. J. Hered., 77, 341-344.

ROWE, K. E. AND COCKERHAM, C. C. 1963. Relation between performance and heterozygosity in Drosophila. Genetics, $49,363-366$

SENTZ, J. C., ROBINSON, H. F. AND COMSTOCK, R. E. 1954 Relation between heterozygosity and hybrid vigor in maize. Agron. J., 46, 514-520.

SINHA, S. K. AND KHANNA, R. 1976. Physiological biochemical, and genetic basis of heterosis. Adv. in Agronomy, 27, 123170.

SOULE, M. 1979. Heterozygosity and developmental stability: another look. Evolution, 33, 396-401.

SHEkidan, A. K. 1981. Cross breeding and heterosis. Anim. Breed. Abst., 49, 131-144.

TACHIDA, H. AND MUKAI, T. 1985. The genetic structure of natural populations of Drosophila melanogaster. XIX Genotype-environment interaction in viability. Genetic.s, 111, 43-55.

TANKSLEY, D., MEDINA-FILHO, H. AND RICK, C. M. 1982. The effect of isozyme selection on metric characters in an interspecific backcross of tomato-basis of an early screening procedure. Theor. Appl. Genet., 60, 291-296.

TANKSLEY, D. AND ORTON, T. J. 1983. Eds. Isozymes in Plant Genetics and Breeding, Part A+B, Elsevier Science Publishers, Amsterdam.

WHITTINGTON, W. J. 1973. Genetic regulation of germination. In Heydecker, W. (ed.) Seed Ecology, The Pennsylvania State University Press, University Park, PA, pp. 5-30. 